\title{
From sentence negation to connective. Old Lithuanian nei(gi) 'and not; nor; than; before'
}

\author{
NORBERT OSTROWSKI \\ Adam Mickiewicz University in Poznań
}

This paper aims to show the sources of the Lithuanian conjunction nei(gi) 'than' and its later development. The most archaic function of nei that can be found in Old Lithuanian texts is nei 'and not' as a type of sentence negation in a clause following another clause that does not contain a negation, with both clauses combined asyndetically. Examples can be divided into two subtypes, defined as UNORDERED ADDITION and TEMPORAL SUCCESSION CLAUSES in Dixon's terms (Dixon 2009). The counterparts of nei are Latin ne-que and German und nicht. The next stage in the development of coordinate sentences with nei was correlative sentences of the type ne-... nei(gi) 'not ... nor', which were very common in the 16th century. The correlative construction ne- ... nei(gi) 'not ... nor' traces back to juxtaposed clauses with narrow-scope negation, viz. $\neg \mathrm{p} \&$ \& $\neg$ ('We didn't meet Marvin, and we didn't meet Joan either')—Haspelmath (2007, 16). Negative coordination of the type ne-... nei(gi) underlies reduplicated connectives nei ... nei 'neither ... nor', which are widespread in modern Lithuanian. ne- ... nei(gi) also gave rise to the conjunction of comparative clauses nei(gi) 'than'. (Pirm) nei(g) 'before', as a conjunction of temporal clauses, belongs to the latest chronological layer.

Keywords: diachronic linguistics, coordination, subordination, sentence negation, comparative constructions

\section{The goal and structure of the article}

One of the most neglected fields in diachronic descriptions of Lithuanian, and Baltic languages in general, is the development of coordinate clauses and hence the etymology of coordinating connectives ( = coordinators). This state of affairs is due, among other things, to insufficiently analysed data from Old Lithuanian texts. We can say that although the historical description of subordinate clauses in Lithuanian (and Latvian) has been the subject of some studies (e.g. Holvoet 2000, 2010, Pajedienè 2012), ${ }^{1}$

\footnotetext{
${ }^{1}$ On participial and infinitival constructions in Baltic see Ambrazas (1990, 1995, 2006).
} 
coordination has never aroused much interest among researchers. For instance, in the historical syntax of Lithuanian by Ambrazas (2006), which presents a synthesis of hypotheses put forward so far, the few remarks about coordination are dispersed in various chapters. A rare exception to the rule is the paper by Judžentis \& Pajèdienè (2001). This is why works from the beginning of the 20th century, such as studies by Leskien (1903), Hermann (1912) and Fraenkel (1926) are still considered valuable.

The inadequacies in the synchronic description of language in the oldest texts adversely affect etymology. An example of this is the account of the Lithuanian/Latvian negation nei in Fraenkel's (1962) and Smoczyński's (2007) etymological dictionaries, whose authors do not go beyond the trivial equation of Lith. nei ... nei = Slav. ni ... ni 'neither ... nor'. Actually, Lith. nei ... nei 'neither ... nor' is a late innovation, not a remnant of the period of Balto-Slavic unity, cf. section 1.2. This paper aims to show how a philological analysis of the oldest Lithuanian texts can help us to follow the functional changes of nei. In this way we are able to separate different chronological layers and point to innovations following in succession. As the author of this paper is primarily interested in the history of Baltic languages, the typological data are exploited here to a lesser extent. I am aware that the changes presented in the article may seem trivial to a typologist; however, the less exotic the change, the more probable it is that the diachronic description offered is correct. Secondly, tracing the historical changes might be a no less fascinating adventure than a typological depiction would be.

The most archaic function of nei, which can be found in Old Lithuanian texts, is nei as a sentence negation in a clause following another clause that does not contain a negation, with both clauses combined asyndetically. Examples can be divided into two subtypes that can be defined as UNORDERED ADDITION and TEMPORAL SUCCESSION CLAUSES in Dixon's terms (Dixon 2009). Counterparts of nei are Latin ne-que and German und nicht. The next stage in the development of nei was correlative sentences of the type ne-... nei(gi) 'not ... nor', very common in the 16th century. This type of sentence traces back to juxtaposed clauses with narrow-scope negation (section 1.1). It was only the type ne- ... nei(gi) 'not ... nor' (CoNTRASTIVE NEGATIVE COORDINATION in Haspelmath's (2007) terms) that then gave rise to nei ... nei 'neither ... nor', which is common in modern Lithuanian (section 1.2). Negative coordination of the type ne-... nei(gi) also gave rise to the connective of comparative clauses nei(gi) 'than', the PARTICLE 
COMPARATIVE in Stassen's (1985) terms (section 2). The latest chronological layer is nei 'before' used as a connective of adverbial time clauses. This change illustrates the shift from a qualitative comparison of two actions to a comparison of two actions in time, i.e. 'than' $>$ 'before'. Such a shift is the reverse of a change described by Stassen $(1985,61)$ for Dutch dan 'than', which comes from dan used adverbially in temporal succession clauses, i.e. 'then' > 'than', cf. Heine (1997, 117), section 2.

\section{Lith. nei(gi) 'nor' as a coordinator of contrastive negative coordination}

$$
\text { 1.1. Lithuanian ne-... nei(gi) 'not ... nor' }
$$

In this type, a coordinated clause introduced by the coordinator nei 'nor' follows a clause with sentence negation ne-, cf. (1)-(4). In Old Lithuanian texts of the 16th century this kind of negative coordination prevails over the second subtype nei(gi) ... nei ... / nei ... nei(gi) 'neither ... nor', cf. 1.2.

(1) Schitai, anis man ne tike-s, nei mano behold they 1sG.DAT NEG believe-FuT.3 nor my bals-a klausi-s, bet sakj-s... (BВ) voice-GEN.SG hearken-FUT.3 but say-FUT.3

'But, behold, they will not believe me, nor hearken unto my voice: for they will say ...' (Exod. 4.1)

(2) aß iiémus nê liepíeu / nei-g ium-p

I.NOM they.DAT.PL NEG order.PST.1SG NEG-FOC you[PL]-ALL

kałbêíau: (DP 246.36-37)

say.PST.1SG

'I did not order them, nor said to them...'

(3) Ir klause ghi/ ir biloia yamui/

and ask.PST.3 he.ACC.sG and say.PST.3 him.DAT.sG

kamgi tu Chrikschtighi/ kada tu ne essi why you baptize.PRs.2sG if you NEG be.PRs.2sG

Christus nei Helioschius / nei Prarakas? (veE 7.15-17)

Christ NEG Elias NEG prophet

'And they asked him, and said unto him, Why baptizest thou

2 The English renderings come from the King James Bible (Authorized Version), Pure Cambridge Edition. 
then, if thou be not that Christ, nor Elias, neither that prophet?' (John 1.25)

(4) Todel brol-ei ne-kleideket: [...] Nei

therefore brother-NOM.PL NEG-err.IMP.2PL NEG

pardůket nei-gi pirket (Mž 371.12-15)

sell.IMP.2PL NEG-FOC buy.IMP.2PL

'Therefore, my brothers, do not err [...] neither sell, nor buy.'

Sentences (1)-(4) have two striking features in common. Firstly, the negative coordinator nei(gi) always introduces the second and following clauses, cf. (3). That is, it is possible to have ne-... nei, but not *nei ... ne-. The same state of affairs is evidenced:

(a) in Latvian, cf. es tuo nedarǐšu, nei man klātuos tuo darìt. 'I will not do this, and it is unseemly for me to do this' (ME 2, 715),

(b) in the Latgalian dialect of Latvian (Evangelia toto anno 1753), cf. Kopec tad krysti, kad na essi tu Chrystus, ni Eliasz, ni Profets? (EVTA 4.2-4) 3 'Why baptizest thou then, if thou be not that Christ, nor Elias, neither that prophet?' (John 1.25),

(c) in Slavic, e.g. ne truždajutb se, ni predutb 'they toil not, neither do they spin' (Miklosich 1868-1874, 183), ni < *nei. ${ }^{4}$

Secondly, the focus particle -gi is always added to nei (2), or, if nei is repeated, to the last one (4), therefore we have ne-... neigi but never *negi ... nei. This rule applies also to Old Latvian ne- ... nedz 'neither ... nor', where $-d z<-g i(5)$, and Old Prussian, cf. ni perweckammai ne-ggi ernertimai 'nicht verachten noch erzürnen' ('we should neither hold in contempt nor enrage')—(Enchiridion 31.4-5).

(5) Na-war kùk-s tob-s, stykt-us OLatgalian NEG-can.PRs.3 tree-NOM.SG good-NOM.sG bad-ACC.PL

augl-us dù-t: ne-dz kùk-s stykt-s, fruit-ACC.PL give-INF NEG-FOC tree-NOM.SG bad-NOM.SG łob-us augl-us dù-t. (EVTA 56.4-5)

good-ACC.PL fruit-ACC.PL give-INF

${ }^{3}$ The Latgalian $n i$ is probably a result of the change *nei > *nie > ni (Mažiulis 1996, 181).

${ }^{4}$ Cf. OCS Ne dadite / s[vę]tago psomъ. ni pomětaite biserı vašichъ prědъ sviniěmi [...] (Codex Zographensis) 'Give not that which is holy unto the dogs, neither cast ye your pearls before swine’ (Matt. 7.6). 
'A good tree cannot bring forth evil fruit, neither can a corrupt tree bring forth good fruit.' (Matt. 7.18)

The enclitic particle -gi was a marker of contrastive focus ${ }^{5}$ and this usage is obvious in (6), where the focus is also graphically marked, by using the capital letter in < Penktangi > 'fifth'. The clause, being in the scope of the focalized coordinator nei-gi, expressed contrast, i.e. the whole sentence could be paraphrased along the lines of 'not X, and not Y either'. The focalizer -gi was added optionally, cf. (1) and (3).

(6)

Potam isch-gulda iemus Penkt-an-gi

then PRV-lecture-PST.3 them.DAT.PL fifth-ACC.SG-FOC

prisakim-a sawa dang-aus Tiew-a.

commandment-ACC.SG his heaven-GEN.SG father-GEN.SG

(BP II 284.18-19)

'Then he lectured them on the fifth commandment of his heavenly Father'

Martin Haspelmath (2007, 14-17), when describing CONTRASTIVE NEGATIVE COORDINATION (e.g. neither... nor), a negated variant of CONTRASTIVE COORDINATION, e.g. both $A$ and $B$, either $X$ or $Y,{ }^{6}$ noticed, among other things, that neither ... nor may be interpreted either as a conjunction with narrow-scope negation, viz. $\neg$ p \& $\neg$ q ('We didn't meet Marvin, and we didn't meet Joan either'), or a disjunction with wide-scope negation, viz. $\neg(\mathrm{p} \vee \mathrm{q})$ ('We didn't meet either Marvin or Joan') - Haspelmath (2007, 16). Haspelmath's explanation sheds light on the source of the negative coordination ne- ... nei(gi) and nei ... nei(gi) 'neither ... nor' (1.2.). Out of the two options (viz. conjunction vs. disjunction), ne- ... nei(gi) 'not ... nor' as a conjunction with narrow-scope negation is supported by the existence of nei 'and not' in (7)-(9), a kind of sentence containing asyndetic clause-combining where the first clause does not contain a negation. This type has been recorded only in Old Lithuanian texts coming from

\footnotetext{
${ }^{5}$ For more on -gi see Hermann (1926, 106-171), Ambrazas (2006: 80-82), Nau \& Ostrowski (2010: 26-27), Ostrowski (2011, 76-77). By 'marker of contrastive focus' I mean the element "that identifies a subset within a set of contextually given alternatives" (Drubig \& Schaffar 2001: 1079).

6 "it is emphasized that each coordinand belongs to the coordination, and each of them is considered separately. Thus, the following sentence is felicitous only if there was some doubt over one of the conjuncts [...]" (Haspelmath 2007, 14):

Both Guatemala and Belize are in Central America.
} 
East Prussia (Wilent, Bretke, Vaišnora). Counterparts of nei in (7)-(9) are German und nicht / auch nicht (Luther, 1545) and Latin nec / neque / et non (Vulgate), cf.:

(7) Tu pa-min-i mana Szmon-es [...], nei an-u You PRV-oppress-PRs.2sg my people-ACC.PL NEG them-GEN.PL nor- $i$ pa-leis-ti: (вв)

want-PRS.2sG PRV-let-INF

Luther: Du trittest mein Volck noch vnter dich / vnd wilts nicht lassen

Vulgate: Adhuc retines populum meum et non vis dimittere eum?

'As yet exaltest thou thyself against my people, that thou wilt not let them go?' (Exod. 9.17)

(8) Ghis dręba ir siaucz ir kasa

he tremble.Prs.3 and rage.Prs.3 and dig.Prs.3

Szem-es, nei klausa bals-o Trumitt-os. (вB)

ground-ACC.PL NEG obey.PRs.3 sound-GEN.SG trumpet-GEN.SG

Luther: Es zittert vnd tobet vnd scharret in die erde / vnd achtet

nicht der drometen halle.

Vulgate: Fervens et fremens sorbet terram nec consistet, cum tubae sonaverit clangor. ${ }^{7}$

'He swalloweth the ground with fierceness and rage: neither believeth he that it is the sound of the trumpet.' (Job 39.24)

(9) Aesch vsch masz-aus-i daikt-a laikau / I as small-sPRL-ACC.sG thing-ACC.sG think.PRs.1sG

idant nůg yussu bu-czia sudi-t-as /

that by you[PL].GEN be-COND.1sG judge-PPP-NOM.SG.M alba nůg szmonischk-ąs dien-os / nei

or by human-GEN.SG.F gathering-GEN.SG NEG

pats sawe taipa-ieg

self.NOM.SG.M RFL.ACC in_this_way-FOC

sudiyu. (veE 5, 17-19; 1 Cor 4.3)

judge.1sG

Luther: Mir aber ists ein geringes / das ich von euch gerichtet werde / oder von einem menschlichen Tage / Auch richte ich mich selbs nicht.

\footnotetext{
${ }^{7}$ For other instances of this kind, cf. Ostrowski (2008).
} 
Vulgate: Mihi autem pro minimo est, ut a vobis iudicer aut ab humano die. Sed neque meipsum iudico.

'But with me it is a very small thing that I should be judged of you, or of man's judgment: yea, I judge not mine own self.' (1 Cor. 4.3)

A parallel for the elucidation of the Lith. ne-... nei(gi) presented here is provided by Gothic ni-h (lit.) 'not and' and Latin ne-que in (10):

(10) ni maurnaip saiwalai izwarai Gothic NEG take_thought.oPT.PRS.2PL soul.DAT.SG your[PL].DAT.SG.F hwa matjaip jah hwa drigkaip nih what eat.oPT.PRs.2PL and what drink.opT.PRs.2PL NEG leika izwaramma hwe wasjaip. body.DAT.SG your[PL]-DAT.SG how dress.OPT.PRS.2 PL Vulgate: Ne solliciti sitis animae vestrae quid manducetis, neque corpori vestro quid induamini.

OLith.: nerupinkities apie ßiwata yusu / ka turietumbite walgiti ir // gerti. Ney taipaieg apie kuna yũsu ků turietumbite wilketi. (VEE 111.5-7)

'Take no thought for your life, what ye shall eat, or what ye shall drink; nor yet for your body, what ye shall put on.' (Matt. 6.25)

Sentences (7)-(9) are instances of so-called UNORDERED ADDITION (Dixon 2009, 26). ${ }^{8}$ The second, less common subtype is TEMPORAL SUCCESSION clauses: 'X, and following after X, Y' (Dixon 2009, 9), cf. (11). Both kinds of and-coordination, i.e. UNORDERED ADDITION and TEMPORAL SUCCESSION, can be conveyed asyndetically (Dixon 2009, 37-8) and Lithuanian examples (7)-(9) and (11) meet this condition.
(11) Diew-as
nu-schlosti-s
wiss-as
aschar-as nůg
God-NOM.SG PRV-wipe-FUT.3 all-ACC.PL.F tear-ACC.PL from

\footnotetext{
${ }^{8}$ Unordered addition "involves two distinct events which are semantically or pragmatically related but for which no temporal sequence is assumed. For example: Mary peeled the potatoes and John shelled the peas.

Both actions relate to the preparation of food. There is no time specification here-the potatoes may have been dealt with first, or last, or the activities may have been simultaneous or overlapping. Temporal information is not considered relevant and is not stated. (If then were added after and, it would create a statement of sequentiality.)" (Dixon 2009, 26)
} 
iu aki-u/ nei bus potam

them.GEN.PL eye-GEN.PL NEG be.FuT.3 after

Smert-ies/ [...]/ nei schauksm-o / nei sopeghim-o

Death-GEN.SG NEG scream-GEN.SG NEG pain-GEN.SG

(BP II 13.12-14)

'And God shall wipe away all tears from their eyes; and there shall be no more death, neither sorrow, nor crying, neither shall there be any more pain.' (Rev. 21.4)

\subsection{Lithuanian nei ... nei(gi) / nei(gi) ... nei 'neither ... nor'}

In modern Lithuanian CONTRASTIVE NEGATIVE COORDINATION is expressed by the reduplicated connectives nei ... nei 'neither ... nor' and both of them occur in the scope of the sentence negations ne- (12). Also possible is the variant with the negation ne- omitted, as in (13)-(14), cf. Ambrazas, ed. $(1997,671)$.

(12) Žmon-ès nei ne-matè, nei people-NOM.PL neither NEG-See.PST.3 nor ne-girdejo artejjanči-os audr-os. NEG-hear.PST.3 approaching-GEN.SG storm-GEN.SG 'People neither saw (lit. 'not-saw') nor heard (lit. 'not-heard') the approaching storm.' (Ambrazas, ed., 1997, 671)

(13) Žmon-ès nei maté, nei girdejo people-NOM.PL neither see.PST.3 nor hear.PST.3 artejjanči-os audr-os. approaching-GEN.SG storm-GEN.SG

'People neither saw nor heard the approaching storm.' (Ambrazas, ed., 1997, 671)

(14) Weisde-ki-te ant pauksczi-u Dang-aus / iog ghie look-IMP-2PL at bird-GEN.PL sky-GEN.SG that they ney seja/ ney piauja/ ney su-renka neither sow.PRs.3 nor reap.PRs.3 nor PRV-gather.PRS.3 klůn-ůsna (vEE 111.5-7)

barn-ILL.PL

Gothic: insaihip du fuglam himinis, pei ni saiand, nih sneipand nih lisand in banstins. 
Vulgate: Respicite volatilia caeli, quoniam non serunt neque metunt neque congregant in horrea.

'Behold the fowls of the air: for they sow not, neither do they reap, nor gather into barns' (Matt. 6.26)

Sentences like (12) are extremely rare in Old Lithuanian texts. They are not found in Mosvid's (1547-1570) and Wilent's (1579) works (WestAukštaitian dialect) at all, but are instanced in the first part of Punktay sakimu (1629) by the Lithuanian Jesuit priest Konstanty Szyrwid (EastAukštaitian dialect). More common were examples like (13)-(14), although this type (i.e. nei ... nei) was also definitely less frequent than ne... nei(gi) 'not ... nor'. In Wilent's Euangelias bei Epistolas (1579) the ratio of ne-... nei(gi) to nei ... nei was $20: 2$. Taking into account the subsequent increase in usage of nei ... nei 'neither ... nor', one can suppose nei ... nei to have been a later Lithuanian innovation, despite the presence of an identical structure ni ... ni 'neither ... nor' in Slavic. Interestingly, nei ... nei is missing in Old Prussian. The spread of nei to the first clause has a parallel in Latin nec ... nec 'neither ... nor' and Gothic nih ... nih 'neither ... nor', cf. gakunnaip blomans haipjos, haiwa wahsjand; nih arbaidjand nih spinnand (Matt. 6.28) 'Consider the lilies of the field, how they grow; they toil not, neither do they spin'.

What caused the dislocation of nei to the beginning of the first clause? The origin of this change was possibly determined by the desire to focalize the first clause. In the sequence ne- ... nei 'not ... nor', described in 1.1 , the contrastive particle -gi could be attached only to nei, never ne-, therefore ne- ... neigi, but not *negi- ... nei. In other words, only the second clause, introduced by nei, optionally reinforced by -gi, could be highlighted, not the first one. However, such a restriction does not operate in the case of nei ... nei 'neither ... nor', where both nei-gi ... nei (15) and nei ... nei-gi (16) were possible.

(15) Nei-gi wel delei nekoki-u papiktinim-u / NEG-FOC again due_to some-GEN.PL depravity-GEN.PL kur-ie ne-koro-t-i at-liek-t / which-NOM.PL.M NEG-punish-PPP-NOM.PL.M PRV-remain-PRS.3 tur bu-ti Baßnicz-a ap-leif-t-a / must.PRS.3 be-INF church-NOM.SG PRV-abandon-PPP-NOM.SG.F nei waid-as jra dari-tin-as NEG dispute-NOM.SG be.PRS.3 do-PNEC-NOM.SG.M 
moxl-e / kad nce iak-ia blud-a

doctrine-LOC.SG that NEG any-GEN.SG.M error-GEN.SG

moxl-e nara / kaip apie tatai Powil-as

doctrine-LOC.SG NEG.be.PRS.3 as about this Paul-NOM

aschtrai ap-rascha 1. Cor. 1. (MT 103v.10-14)

gravely PRV-write.PRs. 3

'Nec propter aliqua scandala, quae impunita manent, Ecclesia deserenda, et schisma faciendum est, si nullus sit error in doctrina, ut gravissime Paulus praecepit.'

'Neither due to any moral corruption which remains unpunished may the church be abandoned, nor should any dispute arise over the doctrine, as there is no error in the doctrine, as Paul gravely teaches in 1 Cor. 1 .'

(16) Ifchtogi nei iem intiktinai gal tarnau-ti, therefore neither him faithfully might.PRs.3 serve-INF nei-gi ifchgani-t-u pafto-ti (MT XXIII.14-15)

nor-FOc redeem-PPP-INS.SG become-INF

'Therefore [he] can neither faithfully serve Him [God], nor be redeemed.'

\section{Lithuanian comparative constructions with nei(gi) 'than'}

Beginning from the first Lithuanian texts nei(gi) appears as a conjunction of comparative clauses, cf.:

(17) $\mathrm{Er}$ ne did-esn-is daikt-as sziwat-s /

PTCL NEG big-CMPR-NOM.SG.M thing-NOM.SG life-NOM.SG

neigi walgim-s? Ir kun-s neigi

than meat-NOM.SG and body-NOM.sG than

rub-ay? (VEE 111.8-9)

raiment-NOM.PL

'Is not the life more than meat, and the body than raiment?'

(Matt. 6.25)

(18) Bet esch daugi-aus dirbau / neig kurs-ai

but I much-CMPR labour.PST.1sG than anyone-PTCL

isch yũ (VEE 102.16-17)

among them.GEN.PL 
'But I laboured more abundantly than they all' (1 Cor. 15.10)

In modern Lithuanian the variant neig(i) 'than' is no longer used, but in the 16th century the majority of authors showed predilection for neig(i) rather than nei. In Wilent's works the ratio of nei to neig was $1: 6$. Only Bretke diverged from the others and the ratio of nei : neig in his Postilla (1591) was 55 : 6; Bretke's tradition eventually got the upper hand in Lithuanian.

In Stassen's typology (1985, 2001), examples (17)-(18) are instances of the PARTICLE COMPARATIVE, a type very common mainly in Europe. Of 18 particle comparatives collected by Stassen, 13 are evidenced just in Europe (Haspelmath 2001, 1499). The remaining part of the examples come from West-Indonesian languages. A distinctive feature of this type is the presence of a connective linking the standard of comparison and the comparee; moreover, the comparee often has a morphological marker of comparative, e.g. -esn- and -'aus in (17)-(18). Unlike conJoINED COMPARATIVES, the PARTICle COMPARATIVE does not have the form of a coordination of clauses, ${ }^{9}$ but displays some features in common with coordination. Firstly, the connective is sometimes etymologically connected to a coordinating conjunction, e.g. baino 'than / but' in Basque, na 'than / nor' in Scottish Gaelic, nor 'than / nor' in Scottish English, Polish ni-ż / (Old Polish) ni-że 'than'. ${ }^{10}$ Secondly, the PARTICLE COMPARATIVE allows gapping, which is commonly argued to be a feature of coordination (Stassen 1985, 46-7, 190-1; 2001, 995-6), cf. Lithuanian instances (19a) and (19b)Holvoet \& Judžentis (2003, 144):

(19a) Jon-as béga greiči-au negu Petr-as.

John-NOM run.PRs.3 fast-CMPR than Peter-NoM

'John runs faster than Peter.'

(19b)Jon-as béga greiči-au, negu Petr-as béga.

John-NOM run.PRs.3 fast-CMPR than Peter-NOM run.PRs.3

\footnotetext{
${ }^{9}$ In CONJOINED COMPARATIVES the comparison is not expressed directly, but inferred from the fact that the compared clauses contain antonymous predicates or predicates conveying a positive-negative polarity (Stassen 1985, 38, 44; Cristofaro 2003, 46), cf.:

Kaw-ohra naha Waraka, kaw naha Kaywerye (Hixkaryana).

tall-not he_is Waraka tall he_is Kaywerye

'Kaywerye is taller than Waraka'

${ }^{10}$ Cf. Polish ni as a coordinator: Ni pies, ni wydra 'Neither dog, nor otter' (nobody knows

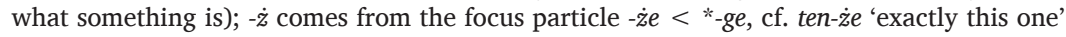
: ten 'this'.
} 
'John runs faster than Peter runs.'

Old Lithuanian connectives neg, nei(g), neng, nent, net and nekaip 'than' contain the negation ne, and some of them are recorded also in the function of sentence negation. For instance OLith. neg(i) 'than', resulting from conflation of $n e$ 'not'11 and the aforementioned focus particle -gi, appears in (20)-(21) in a juxtaposed clause expressing contrast ${ }^{12}$ to the preceding one:

(20) Ko teip skubin-tei-s - ne-gi dega.

what-GEN.SG So rush-INF-RFL NEG-FOC burn.PRS.3

(LKž 8: 619-Tauragènai)

'Why are we to hurry up so much, there's no rush (lit. 'it does not burn').'

(21) Teip' gáli-mę $\int u \quad$ wêrkę-ncz-iu Petr-ú bû-t so can-PRs.1PL with weep-PPA-INS.SG.M Peter-INS.Sg be-INF iżgant-t-i ne-g $\int u \quad n u \int i m i n-u \int i-i u ̛ i u$ redeem-PPP-NOM.PL.M NEG-FOC with grieve-PPA-INS.SG.M.DEF Iudôßiumi bû-t páfmerk-t-ais. (DP 162.39)

Judas-INS.SG be-INF condemn-PPP-INS.PL.M

Pol. 'Tak możemy z płaczącym Piotrem być zbawieni / ktorzysmy z rospaczaiącym Judaszem mogli być potępieni.'

'Therefore we can be redeemed with crying Peter, and not be condemned with grieving Judas.'

Interesting is an instance of Lith. negu 'than', cf. (19a)-(19b). As a connective of comparative clauses negu seems to have appeared very late. It was still lacking in the folk-tales published by Schleicher (1857). In Old Lithuanian texts ne-gu appeared exclusively in rhetorical questions; the enclitic -gu was a question particle (cf. Nau \& Ostrowski 2010, 27) and ne- served as a sentence negation, $\mathrm{cf}$. (22)— $\mathrm{Ps}^{1}$ 281.25-26:
(22) Ir priei-i
tarn-ai
Wießpat-ies [...]
and come-PPA.NOM.PL.M servant-NOM.PL householder-GEN.SG

\footnotetext{
${ }^{11}$ Also the negation ne 'not' alone may serve in Baltic languages as a comparative connective 'than' (cf. Mīlenbachs 1891/2009; Petit 2009).

12 "The connection of contrast means that in the speaker's opinion two propositions A and $\mathrm{B}$ are valid simultaneously and proposition B marks a contrast to the information given in proposition A." (Rudolph 1996, 20)
} 
tare iam: Wießpat-ie, Ne-gu gier-u

say.PST.3 him.DAT.sG lord-voc NEG-PTCL good-ACC.SG

sekt-u pa-seiey vnt dirw-os tawo?

seed-ACC.SG PRV-SOW.PST.2SG on field-GEN.SG thy

'So the servants of the householder came and said unto him, Sir, didst not thou sow good seed in thy field?' (Matt. 13.27)

But as a sentence negation negu emerges in (23), cf.:

(23) Negu prieš ji rank-ą kel-si. (LKž 8: 622)

NEG against him.ACC.sG hand-ACC.sG raise-FuT.2sG

'But you will not raise a hand against him.'

Slightly different is the origin of OLith. net 'than'13 (e.g. вв Esther 6.6). In Bretke's works net comes up first of all in adversative sentences marking-like German sondern-'substitutive adversative coordination' (Haspelmath 2007, 28), cf. (24):

(24) betai-g ne mana walia/ net tawa te-nusidůs-t but-FOC NEG my will but yours OPT-happen-PRs.3

(BP 194.1-2)

'Nevertheless not my will, but thine, be done' (Luke 22.42)

Here also both clauses are coordinated and contrasted. The case of net is reminiscent of a subtype of conjoined comparative called 'antonymy' by Heine $(1997,117)$ (' $X$ has property $p$ while $Z$ has the opposite property $\left.q^{\prime}\right) .{ }^{14}$

The examination of the examples with neg(i), negu and net betrays the functional closeness of these items. By assuming the sentence negation itself to have given rise to connectives of comparative clauses, we gain the possibility of establishing the origin of Lith. neig 'than'. Its source was juxtaposed sentences, in which the second clause conveyed contrast relative to the first one, and the focus particle -gi was a marker of contrast. This state of affairs is clearly visible in (25):

${ }^{13}$ net (Old Lithuanian neta / nete) 'but; unless; until; because; than; in order to' developed from the combination of the negative particle ne and enclitic forms of the demonstrative pronoun -ta / -te (Hermann 1912, 82-3).

${ }^{14} \mathrm{Cf}$. Mastingcala king waste, tka singthela king sice (Dakota)

rabbit the good but rattle-snake the bad

'The rabbit is better than the rattle-snake' 
(25) Sakau yumus tas-ai nueja

tell.PRs.1sG you[PL].DAT this-PTCL go_down.PST.3

ap-teisin-t-as nam-ůsna sawa nei-g anas.

PRV-justified-PPP-NOM.SG.M house-ILL.PL his NEG-FOC other

(VEE 103.12)

'Jch sage euch / Dieser gieng hinab gerechtfertiget in sein haus / fur jenem'15 (Luther 1545)

'I tell you, this man went down to his house justified rather than the other' (Luke 18.14)

In (25) we see ellipsis of the predicate, which resembles the PARTICLE COMPARATIVE described above (19a)-(19b). The first clause (i.e. Sakau yums...) and the second one (viz. neig anas) are juxtaposed and contrasted. The similarity between (20)-(21) and (25) is obvious. However, it gives rise to a question: in what kind of sentences did neig (25) come into being? Examples (7)-(9), i.e. with nei 'and not', seem to be less probable. Firstly, they do not express contrast. Secondly, the negation nei in (7)-(9) never takes -gi, which results from the first observation. Thirdly, the aforementioned parallel of Scottish Gaelic na 'than / nor' and Irish ná 'than / nor' speaks for ne-... nei(gi) in (1)-(4) as a source of neigi (25). The Irish counterpart of English neither ... nor is a single word ná following the clause with the sentence negation nil (26) — (Haspelmath 2007, 17). Such a construction is an exact equivalent of the Lith. ne-... nei(gi).

(26) Ní mac ná iníon aige. Irish NEG.is son nor daughter at_him

'He doesn't have a son nor a daughter.'

In this way we come to the conclusion that comparative clauses with nei(gi) 'than' represent a change from a sentence containing asyndetic clause-combining to the subordination of a comparative clause, but this subordination still conveys some characteristics of coordination. Apart from gapping, the second feature is the impossibility of clause extraposition in (27):

(27) *Ne-gu Petr-as, Jon-as bega greiči-au. than Peter-NOM John-NOM run.PRs.3 fast-CMPR *'Than Peter, John runs faster'

${ }^{15}$ MHG für / vür / vüre 'statt, statt dessen' (Lexer 1992). 
This restriction does not hold, however, in (28), where neg 'before' functions as a connective of a temporal clause:

(28) neg Abrôm-as bů/ iau aß ęmi. (DP 130.29)

before Abraham-Nom be.PST.3 already I be.PRs.1sG

'Before Abraham was, I had already been.'

It is interesting that the connectives neg(i), nei(gi), neng 'than' were also used in temporal clauses in the Old Lithuanian period. As shown in the table below, there existed a strict connection between neg(i), nei(gi), neng 'than' and 'before', i.e. the authors who did not use e.g. neng 'than' (Dauksza, Szyrwid), did not use neng 'before' either, cf.:

Table 1. The use of neng, neg(i) and nei(gi) in Old Lithuanian texts

\begin{tabular}{|c|c|c|c|c|c|c|}
\hline & \multicolumn{2}{|c|}{ neng } & \multicolumn{2}{|c|}{$\operatorname{neg}(i)$} & \multicolumn{2}{|c|}{ nei(gi) } \\
\hline & 'than' & 'before' & 'than' & 'before' & 'than' & 'before' \\
\hline Wilent (VEE) & + & + & - & - & + & + \\
\hline Dauksza (DP) & - & - & + & + & - & - \\
\hline Bretke (вP) & + & + & - & - & + & + \\
\hline Szyrwid (Ps $\left.{ }^{1}\right)$ & - & - & + & + & - & - \\
\hline
\end{tabular}

The philological analysis of Old Lithuanian texts brings to our attention the change 'than' $>$ 'before'. That is, we see a shift from qualitative comparison of two actions to comparison of two actions in time; $\mathrm{cf}$. Pajèdienè (2012, 51-63), who described thoroughly the usage of neg(i), nei(gi), neng 'before, by the time' in Old Lithuanian texts. She showed, among other things, that neg(i), nei(gi), neng 'before' used to appear following a clause with adverb pirm(a) 'first', cf. (29), or even made up a cluster pirm neg 'before' (lit. 'first than') (30), comparable to Old Polish pierwej (wprzód) niz 'before' (lit. 'first than'):

(29) sweria pirm żodźi-us negi $\mathrm{ku}$ weigh.PRs.3 first word-ACC.PL than what.ACC.SG 
iź-taria (PS ${ }^{2}$ 5.13)

PRV-SaY.PRS. 3

Pol. waźy słowa wprzod / niź co wymowi

'(he) weighs first words before he says anything'

(30) Kur-iu buw-a pramin-t-as nůg// Angel-a /

which-INS.sG be-PST.3 name-PPP-NOM.SG.M by angel-ACc.sG

pirm neng sziwat-e prassideia. (VEE 20.9-10)

before than womb-Loc.sG begin.PST.3

'which was so named of the angel before he was conceived in the womb' (Luke 2.21)

The shift from a qualitative comparison of two actions to a comparison of two actions in time in Old Lithuanian and Old Polish ('than' > 'before') is in some ways the reverse of a change described by Stassen $(1985,61)$ for Dutch dan 'than', which traces back to dan used in temporal succession clauses, i.e. 'then' > 'than', cf. (31a)-(31b):

(31a) Eerst ga ik, dan gaat Jan

Dutch

first go I then goes Jan

'First I will go, then Jan will go.' (Stassen 1985, 61, Heine 1997, 117)

(31b) Jan is groter dan Piet.

Jan is taller than Piet

'Jan is taller than Piet.'

\section{Conclusions}

1. The most archaic function of nei that can be found in Old Lithuanian texts is represented by sentences of the type Ghis dręba ir siaucz ir kasa Szemes, nei klausa balso Trumittos. (вв) 'He swalloweth the ground with fierceness and rage: neither believeth he that it is the sound of the trumpet.' (Job 39.24). In this kind of sentence nei 'and not' functions as a type

\footnotetext{
${ }^{16}$ This development, also accepted for Engl. than, cf. Germ. dann < MHG danne / denne '(adv.) dann, damals; (in comparative clauses) denn, als' (Lexer 1992, 29), has been paraphrased by Heine $(1997,117)$ as ' $X$ has property $Y$, and only then $Z$ follows (i.e., $Z$ has less of $Y$ than $X$ has)'. As for symbols $X, Y$ and $Z$, cf.:

David is smart- er than Bob. (Heine 1997, 110)

$\begin{array}{lllll}\mathrm{X} & \mathrm{Y} & \mathrm{D} & \mathrm{M} & \mathrm{Z}\end{array}$

( $\mathrm{X}=$ comparee, $\mathrm{Y}=$ predicate, $\mathrm{D}=$ degree marker, $\mathrm{M}=$ marker of standard, $\mathrm{Z}=$ standard.)
} 
of sentence negation in a clause following another clause that does not contain negation, with both clauses combined asyndetically. The counterparts of nei are Latin ne-que / nec and German und nicht, cf. Vulgate: Fervens et fremens sorbet terram nec consistet, cum tubae sonaverit clangor and Luther (1545) Es zittert vnd tobet vnd scharret in die erde / vnd achtet nicht der drometen halle. (Job 39:24).

2. Examples with the sentence negation nei 'and not' can be divided into two subtypes, defined as UNORDERED ADDITION and TEMPORAL sucCESSION clauses in Dixon's terms (Dixon 2009).

3. The next stage in the development of coordinative sentences with nei were correlative sentences of the type ne-... nei(gi) 'not ... nor', which were very common in the 16th century, e.g. Schitai, anis man ne tikes, nei mano balsa klausis, bet sakjs. (вв) 'But, behold, they will not believe me, nor hearken unto my voice: for they will say.' (Exod. 4.1). These developed from juxtaposed clauses with narrow-scope negation, viz. $\neg$ p \& $\neg \mathrm{q}$ ('We didn't meet Marvin, and we didn't meet Joan either')—Haspelmath (2007, 16).

4. Negative coordination of the type ne-... nei(gi) underlies reduplicated connectives nei ... nei 'neither ... nor', which are widespread in modern Lithuanian. The dislocation of nei to the beginning of the first clause was determined by the desire to focalize the first clause. In the sequence ne-... nei(gi) 'not ... nor', the contrastive particle -gi could be attached only to $n e i$, never ne-, as such a restriction did not operate in the case of nei ... nei 'neither ... nor', where both nei-gi ... nei and nei ... nei-gi were possible.

5 . The usage of nei ... nei 'neither ... nor', common in modern Lithuanian, in the scope of the sentence negation $n e$ - is a late innovation, very rarely found in the 16 th cent. In order to establish the time and the reasons why nei ne-... nei ne- 'neither ... nor' has become so productive, analysis of later texts is an absolute must.

6. The conjunction of comparative clauses nei(gi) 'than' came into being in juxtaposed sentences, in which the second clause conveyed contrast relative to the first clause and the focus particle -gi was a marker of contrast. The source was the aforementioned correlative sentences of the type ne- ... nei(gi) 'not ... nor'. The problem of the origin of Lith. nei(gi) in similative constructions, cf. Piktas néi velnias. (LKž 8: 624) 'Angry like a devil', is still unsettled.

7. nei(g) 'before', a conjunction of temporal clauses, belongs to the latest chronological layer. The context in which the shift 'than' > 'before' 
took place was sentences with the adverb pirm(a) 'first'. Worthy of note is the existence of identical structures in Old Polish, cf. (pierwej) niz 'before' (lit. 'first than').

\section{Norbert Ostrowski}

Uniwersytet im. Adama Mickiewicza w Poznaniu

Instytut Językoznawstwa, Zakład Bałtologii

al. Niepodległości 4, PL-61-874, Poznań

norbertas@poczta.onet.pl

\section{AbBreviations}

ACC - accusative, ACT - active, ALL - allative, CMPR - comparative, COND - conditional, DAT - dative, DEF - definite, $\mathrm{F}$ - feminine, FOC focus, FUT — future, GEN — genitive, ILL — illative, IMP — imperative, INF - infinitive, INS - instrumental, LOC - locative, $\mathrm{M}$ - masculine, NEG - negation, NOM - nominative, oPT — optative, PL - plural, PNEC - participium necessitatis, PPA — past active participle, PPP past passive participle, PRs - present, PRT — particle, PRV — preverb, PST — past, PTCL — particle, RFL — reflexive, SG — singular, SPRL - superlative, voc - vocative

\section{SOURCE TEXTS}

вв = BIBLIA tatai esti Wissas Schwentas Raschtas, Lietuwischkai pergulditas per Jana Bretkuna [...] 1590. Cited from: Jonas Palionis \& Julija Žukauskaitè, Jonas Bretkūnas. Rinktiniai raštai. Vilnius: Mokslas, 1983.

ВP = Jono Bretkūno PostiLE: Studija, faksimilè ir kompaktine plokštelè, ed.

Ona Aleknavičienė, Vilnius: Lietuvių kalbos instituto leidykla, 2005. DP = Postilla Catholicka. Tái est: Iźguldimas Ewangeliu kiekwienos Nedelos ir szwętes per wissús metús. Per Kúnigą Mikaloiv Davkszą Kanonîka Médniku... 1599. Cited from: Jonas Palionis, ed., Mikalojaus Daukšos 1599 metų Postile ir jos šaltiniai. Vilnius: Baltos lankos, 2000. EVTA = Evangelia toto anno, 1753. Cited from: Anna Stafecka \& Ilga Jansone, eds., Pirmā latgaliešu grāmata. Rīga: LU Latviešu valodas institūts, 2004. 
MT = Margarita Theologica ... Zemcżuga Theologischka ... Lituwischkai jra perguldita per Simona Waischnora warnischki ... Karaliaucziuie ... 1600. Cited from: Guido Michelini, ed., Żemczuga Theologischka ir jos šaltiniai. Vilnius: Baltos lankos, 1997.

Mž = Martynas Mažvydas, Katekizmas ir kiti raštai, ed. Giedrius Subačius. Vilnius: Baltos lankos, 1993.

PS = Sirvydas, Konstantinas, Punktay sakimu, 1629-1644. Cited from: Adalbert Bezzenberger, ed., Litauische und Lettische Drucke des 16.

Jahrhunderts. Heft III. Göttingen: Robert Peppmüller, 1882. VE, $\mathrm{VEE}=$ Baltramiejus Vilentas, Enchiridion (VE) and Euangelias bei Epistolas (VEE), Karalauczus, 1579. Cited from: Adalbert Bezzenberger, ed., Litauische und Lettische Drucke des 16. Jahrhunderts. Heft III. Göttingen: Robert Peppmüller, 1882.

http://www.lki.lt/seniejirastai/db.php (corpus of Old Lithuanian texts)

\section{REFERENCES}

Ambrazas, Vytautas. 1990. Sravnitel'nyj sintaksis pričastij baltijskich jazykov. Vilnius: Mokslas.

Ambrazas, Vytautas. 1995. Lietuvių kalbos bendraties konstrukcijų raida. Lietuvių kalbotyros klausimai 33, 74-109.

Ambrazas, Vytautas, ed., 1997. Lithuanian Grammar. Vilnius: Baltos lankos.

AmbrazAs, Vytautas. 2006. Lietuviu kalbos istorine sintakse. Vilnius: Lietuvių kalbos institutas.

Cristofaro, Sonia. 2003. Subordination. Oxford: Oxford University Press. Dixon, R. M. W. 2009. The semantics of clause linking in typological perspective. In: R. M. W. Dixon \& Alexandra Aikhenvald, eds., The Semantics of Clause Linking. A Cross-Linguistic Typology. Oxford: Oxford University Press, 1-55.

Drubig, Hans Bernard \& Wolfram Schaffar. 2001. Focus constructions. In: Haspelmath, König, Oesterreicher \& Raible, eds., 1079-1104.

Fraenkel, Ernst. 1926. Parataxe und Hypotaxe im Griechischen, Baltoslawischen und Albanischen. Indogermanische Forschungen 43, 290-315.

FrAenKel, ERNSt. 1962-1965. Litauisches etymologisches Wörterbuch. Bd. 1-2. Heidelberg: Carl Winter. 
Haspelmath, Martin, EkKehard König, Wulf Oesterreicher \& Wolfgang RAIBLE, eds., 2001. Language Typology and Language Universals. Vol. 2. Berlin-New York: Walter de Gruyter.

Haspelmath, Martin. 2001. The European linguistic area: Standard Average European. In: Haspelmath, König, Oesterreicher \& Raible, eds., 1492-1510.

Haspelmath, Martin. 2007. Coordination. In: Timothy Shopen, ed., Language Typology and Syntactic Description. Vol. 2: Complex constructions. Cambridge: Cambridge University Press, 1-51.

HeIne, BERnd. 1997. Cognitive Foundations of Grammar. Oxford: University Press.

HERMANn, EduARD. 1912. Über die Entwicklung der litauischen Konjunktionalsätze. Jena: Fromannsche Buchdruckerei (Hermann Pohle).

HERMANN, EduARD. 1926. Litauische Studien. Eine historische Untersuchung schwachbetonter Wörter im Litauischen. Berlin: Weidmannsche Buchhandlung.

Holvoet, Axel. 2000. Lietuvių dativus cum infinitivo ir latvių infinityviniai santykiniai sakiniai. Lietuvių kalbotyros klausimai 42, 105-113.

Holvoet, Axel. 2010. Notes on complementisers in Baltic. In: Nicole Nau \& Norbert Ostrowski, eds., Particles and Connectives in Baltic (Acta Salensia, 2). Vilnius: Vilniaus Universitetas / Asociacija "Academia Salensis", 73-101.

Holvoet, Axel \& Artūras JudžEntis. 2003. Sudètinio prijungiamojo sakinio aprašymo pagrindai. In: Axel Holvoet \& Artūras Judžentis, eds., Sintaksinių ryšių tyrimai (Lietuvių kalbos gramatikos darbai, 1). Vilnius: Lietuvių kalbos institutas, 115-172.

JudžEntis, ARtūras \& JūratĖ PAJĖDIENĖ. 2001. Mikalojaus Daukšos Katekizmo (1595) sudètiniai sujungiamieji sakiniai. Acta Linguistica Lithuanica 45, 63-92.

Leskien, August. 1903. Litauische Partikeln und Konjunktionen. Indogermanische Forschungen 14, 89-113.

LeXer, MatTHIAs. 1992. Mittelhochdeutsches Taschenwörterbuch. Mit den Nachträgen von Ulrich Pretzel. 38., unveränderte Auflage. Stuttgart: S. Hirzel. Wissenschaftliche Verlagsgesellschaft.

LKž = Lietuvių kalbos žodynas, vols. 1-20 (1968-2002), Vilnius.

Mažıulis, Vytautas. 1996. Prūsų kalbos etimologijos žodynas. Vol. 3: L-P. Vilnius: Mokslo ir enciklopedijų leidykla. 
ME = MüHLENBACH, KARL. 1923-1932. Latviešu valodas vārdnīca / Lettisch-Deutsches Wörterbuch. Redigiert, ergänzt und fortgesetzt von $J$ [ānis] Endzelins. Bde. I-IV. Herausgegeben vom lettischen Bildungsministerium. Riga.

Miklosich, Franz. 1868-1874. Vergleichende Syntax der slavischen Sprachen. Wien: Wilhelm Braunmüller.

Mīlenbachs, KĀRlis. 1891/2009. Ne, nekā un kā pēc komparatīva. In: Daži jautājumi par latviešu valodu 1, 32-35. Reprinted in: Ina Druviete \& Sarmīte Lagzdin,a, eds., 2009. Kārlis Mülenbachs. Darbu izlase. Vol. 1. Rīga: LU Latviešu valodas institūts, 95-97.

NAu, Nicole \& Norbert Ostrowski. 2010. Background and perspectives for the study of particles and connectives in Baltic languages. In: Nicole Nau \& Norbert Ostrowski, eds., Particles and Connectives in Baltic (Acta Salensia, 2). Vilnius: Vilniaus Universitetas / Asociacija "Academia Salensis", 1-37.

OstrowsKI, NoRBERT. 2008. Istorinès morfologijos ir sintaksės mažmožiai [Miszellen der historischen Morphologie und Syntax.] Baltistica 43.3, 463-473.

Ostrowski, Norbert. 2011. On the origin of the Lithuanian tačiaũ 'but, however, yet'. Lingua Posnaniensis 53.2, 75-81. (http://versita.com/ lp)

PAJĖDIENĖ, JūRATE். 2012. Senosios lietuvių kalbos sudètiniai prijungiamieji laiko sakiniai. PhD thesis. Vilnius.

Petit, DAniel. 2009. Zum Ausdruck der Evidentialität im Baltischen: die litauische Partikel neva. Acta Linguistica Lithuanica 59, 57-80.

Rudolph, Elisabeth. 1996. Contrast. Adversative and Concessive Relations and their Expressions in English, German, Spanish, Portuguese on Sentence and Text Level (Research in Text Theory, 23). Berlin-New York: Walter de Gruyter.

Schleicher, August. 1857. Handbuch der litauischen Sprache. Bd. II: Lesebuch und Glossar. Prag: J. G Calve'sche Verlagsbuchhandlung.

SMoczyŃski, WoJcIEch. 2007. Słownik etymologiczny języka litewskiego. Wilno: Uniwersytet Wileński.

Stassen, Leon. 1985. Comparison and Universal Grammar. Oxford-New York: Basil Blackwell.

Stassen, LeON. 2001. Comparative constructions. In: Haspelmath, König, Oesterreicher \& Raible, eds., 993-997. 